\title{
Indonesia's Shifting Focus of Energy Security Amidst COVID-19
}

\author{
Jovita Komala ${ }^{1}$
}

${ }^{1}$ Faculty of Social and Political Sciences, Universitas Katolik Parahyangan, Indonesia, jovitakomala621@gmail.com

\begin{abstract}
ABSTRAK
Berbagai dimensi dari konsep ketahanan energi menjadikannya topik diskusi besar di saat pandemi. Pergeseran dinamis dari ketahanan energi dapat dilihat baik dalam skala internasional maupun domestik. Makalah ini akan berfokus pada perubahan dinamis ketahanan energi di Indonesia dengan menganalisis kebijakan dan inisiatif energi di masa lalu dan saat ini sesuai dengan konsep yang dielaborasi oleh Melly Caballero. Perbandingan fokus Indonesia pada ketahanan energi sebelum dan selama wabah COVID-19 akan memberikan gambaran yang jelas tentang bagaimana Indonesia mengamankan energi. Argumen utamanya tetap bahwa Indonesia sekarang berfokus pada keamanan sebagai keterjangkauan, bukan ketersediaan dan keberlanjutan. Ini karena, peningkatan tagihan listrik rumah tangga yang dicatat PLN, berbeda dengan aktivitas industri yang menurun membuat permintaan energi nasional melonjak. Kebijakan energi yang disebutkan dalam makalah ini mengacu pada peraturan dan inisiatif pemerintah dari Perusahaan Listrik Negara (PLN). Makalah ini juga akan mengenali masalah yang sedang berlangsung tentang distribusi energi yang tidak merata di luar jaringan Jawa dan melihat bagaimana masalah ini dipengaruhi oleh pandemi.
\end{abstract}

Kata Kunci: COVID-19, Keamanan Energi Indonesia, Kebijakan Energi

\begin{abstract}
Multiple dimensions from the concept of energy security makes it a big topic of discussion in times of a pandemic. The dynamic shift of energy security can be seen both in the international and domestic scale. This paper will focus on the dynamic shift of energy security in Indonesia by analyzing past and current energy policies and initiatives according to the concepts elaborated by Melly Caballero. A comparison of Indonesia's focus on energy security before and during the COVID-19 outbreak will give a clear picture in how Indonesia is securing energy. The main argument remains that Indonesia is now focusing on security as affordability instead of availability and sustainability. This is because of the increased household electric bill recorded by PLN in contrast to the decreasing industrial activities. The energy policies mentioned in this paper refers government regulations and initiatives from the state-owned electric company (PLN). This paper will also recognize the ongoing issue of unequal distribution of energy outside the Java grid and see how this issue is impacted by the pandemic.
\end{abstract}

Keywords: COVID-19, Indonesia's Energy Security, Energy Policy

\section{Introduction}

The politization of energy is a common topic in international relations. To understand why a shift in the focus for energy security is important, a brief discussion on the securitization of energy itself is needed. The theory of securitization, developed by Bary Buzan, Ole Waever, and other collaborators, is the main focus of Copenhagen School. ${ }^{1}$ The theory aims to explain how a certain issue is then recognized as a security issue. The conventional understanding of security itself is then challenged as the broadening of its agenda is necessary for 'security' to encompass issues outside of

\footnotetext{
${ }^{1}$ Buzan, Barry. Ole Wæver and Jaap de Wilde. “Security: A New Framework for Analysis”. United States: Lynne Rienner Publishers, Inc. 1998
} 
military. ${ }^{2}$ The Copenhagen School further elaborated by explaining that in securitization theory, security itself is treated as an outcome of a social process. This social process is a social construction of security issues through "speech-acts". ${ }^{3}$ This is where threats of a certain issue become recognized. Furthermore, widening of "referent object" then becomes possible meaning that the actors or objects that are threatened will include those outside the military issues as well. ${ }^{4}$

One of the most cited events that eventually enhanced the study of energy security was the oil embargo of 1973. This was when member-states from Organization of the Petroleum Exporting Countries (OPEC) refused to export oil. ${ }^{5}$ This kind of disruption to global cooperation left import states in a vulnerable position. In other words, natural resources used as a currency in international relations leads to one of the biggest ties between politics and economy.

Data showing that $30 \%$ of export revenues comes from the oil and gas industry confirms the significance of the energy sector to Indonesia' economy. ${ }^{6}$ Indonesia's efforts to safeguard the country's overall energy security has led to development in the areas of renewable energy. This is not only to anticipate growing demands for energy, as well as maintain export revenues, but is also an effort to achieve SDG 7: Ensure Access to Affordable, Reliable, Sustainable, and Modern Energy for All. As a signatory to the Paris Agreement, government spending have also been allocated to research on sustainable energy. ${ }^{7}$ Considering the non-traditional approach of energy security, Indonesia's biggest challenge is the uneven distribution and accessibility of energy between island as well as urban and rural areas. ${ }^{8} 25$ million people are still without electricity access and most of them live in an isolated area. ${ }^{9}$ Rural areas often shift from kerosene and liquified propane gas to charcoal and fuelwood for the purpose of cutting costs - even though it proves to be a health hazard. ${ }^{10}$ Developing alternative sources for energy aside from oil and coal is seen to be an innovative solution to increase availability and affordability for all Indonesians. Unfortunately, the existing challenge is now worsened by the impacts of COVID-19.

The pandemic originating from Wuhan, China have disrupted the global market for energy. It is forecasted that the global demand for energy will drop 6\%, the worse downfall since the 2008 economic crisis. ${ }^{11}$ This is caused by restrained activities throughout lockdown to "flatten the curve" of infection. As a result, demands for commodities such as coal, oil, gas, and other energy producers spiraled down due to the decline in production activities and transportation usage.

This decline of energy usage in the industrial level is then accompanied by the increase demand coming from household activities. The combination of economic downfall and rising need for electricity leaves more people facing energy insecurity. Hence, it is can be argued that this pandemic

\footnotetext{
${ }^{2}$ Williams, Michael C. "Words, Images, Enemies: Securitization and International Politics”. International Studies Quarterly. (2003): DOI: $10.1046 / j .0020-8833.2003 .00277 . x$.

${ }^{3}$ Michael C Williams, Words, Images, Enemies: Securitization and International Politics.

${ }^{4}$ ibid

${ }^{5}$ Caballero-Anthony, Mely. "An Introduction to Non-traditional Security Studies: A Transnational Approach". Edited by Mely Caballero-Anthony. United States: SAGE Publications Ltd. 2016

6 Soentono, Soedyartomo. "Nuclear Power Development in Indonesia". National Atomic Energy Agency. (1996): http://waste.nuc.berkeley.edu/asia/1997/97ILP Soentono.pdf. (Accessed July 12 2020).

7 Setyowati, Abidah B. "Mitigating Energy Poverty: Mobilizing Climate Finance to Manage the Energy Trilemma in Indonesia". School of Regulations and Global Governance. (2020): https://doi.org/10.3390/su12041603.

${ }_{8}$ Abidah B. Setyowati, Mitigating Energy Poverty: Mobilizing Climate Finance to Manage the Energy Trilemma in Indonesia.

${ }^{9}$ ibid

${ }^{10}$ Melly Cabellero-Anthony, An Introduction to Non-traditional Security.

11 "World Energy Demand to Drop 6\% in 2020: IEA". Greentechlead. (2020): https://greentechlead.com/renewableenergy/world-energy-demand-to-drop-6-in-2020-iea-35993.
} 
altered the government's agenda in safeguarding energy security. This paper aims to analyze how COVID-19 affected Indonesia's approach to energy security, shifting from security as availability and sustainability to security as affordability. Taking both the internal and externalpressure into account, a comparison on the focus of energy security before and during the pandemic.

\section{Conceptual Framework}

\section{Energy Security}

As previously elaborated, cooperation in the global scale through IOs and forums shows the urgency to maintain a strong global chain for the energy sector. Hence, understanding the concepts of energy security becomes a pivotal necessity in the study of International Relations. In the book of Mely Caballero-Anthony, it is stated that some scholars argue that energy security should be a basic human right. Furthermore, it should be considered as the basic dimension of human security. Even so, determining its definition remains an arduous task as it differs between actors. For the purpose of this paper, the definition from the perspective of politicians and diplomats will be highlighted. More specifically, the dimension of security as availability, sustainability, and affordability will be further elaborated.

\section{Security as Availability}

Referring to the supply of 'conventional' sources of fossil energy especially oil, it is understood that the world's oil reserves are not going to last forever. Availability here focuses more on the material itself rather than the price point. ${ }^{12}$ In regards to that, finding alternative sources of energy with a safe way of extraction. Alternative resources include hydropower, nuclear energy and renewables such as solar and wind power. However, it is important to remember that not all member states are privileged to these options as it usually requires large capital and long-term research. This is why the topic of alternative energy is growing to be a controversial one as some states may opt the choice deemed inconsistent with the idea of sustainability.

\section{Security as Sustainability}

The World Commission on Environment and Development mentioned that economic development can be considered sustainable when there is no opportunity cost that will harm future generations. ${ }^{13}$ In this case, the issue of climate change and global warming cannot be ignored. This means that the process of extraction, processing, distribution, and consumption of energy itself must be safeguarded. Furthermore, innovation on finding energy sources should also co-exist with the consideration of environmental and human repercussions. For example, one of the increasingly popular method to extract oil in previously unattainable areas is fracking. ${ }^{14}$ However, fracking itself proves to be very harmful to the environment that will disrupt the ecosystem in the long run.

\footnotetext{
${ }^{12}$ Melly Cabellero-Anthony, An Introduction to Non-traditional Security.

${ }^{13} \mathrm{Ibid}$

${ }^{14}$ Ibid
} 


\section{Security as Affordability}

Non-traditional approach on security as affordability highlights the ability to purchase of communities and households. ${ }^{15}$ The term 'Energy Poverty' becomes a vital point as it is an indicator of insecurity. The aforementioned term refers to a situation where individuals are unable to perform day to day activities as they cannot acquire energy. Unequal access to energy is not only affected by price fluctuations but is also influenced by political and social stability. In this case, the government has the duty of ensuring equal opportunities for all communities to purchase energy. This is especially difficult in rural areas where energy channels are minimum and the per capita income are concerningly low to the point where energy is sacrificed to afford needs considered more primary. The uncomfortable truth is, this type of energy insecurity results in households regressing to unsafe alternatives. In short, this insecurity leads to low quality of life, health hazards and more economic gap due to lack of internet access.

In the world of international relations today, it is safe to say that the concept of energy security itself have been acknowledged. Seen from IOs and forums formed, it shows that memberstates have the urgency to safeguard energy in the traditional and non-traditional sense. As conflicting interest may lead to further politization of global energy chain, several international organizations and forums are formed to maintain a strong relationship between all member-states. There are several international organizations formed especially for the purpose of maintaining energy security. These include International Energy Agency (IEA) whose members are mostly oil-importing countries and OPEC whose members mostly produce and export oil. ${ }^{16}$ Aside from that, there are also forums so that IOs and member states can discuss urgent issues such as International Energy Forum (IEF). ${ }^{17}$

\section{Analysis}

In the midst of COVID-19, the urgency of maintaining energy security does not go away. This paper aims to argue that the change can be seen from the focus on the topic. The analysis will follow the initial hypothesis that Indonesia's energy policy shifted focus from security as availability and sustainability to security as affordability. Hence, an explanation regarding the process of Indonesia's energy policies, energy policies before the COVID-19 outbreak compared with the ones after the outbreak will be analyzed.

\section{a. Decision-making Process for Energy Policy in Indonesia}

Indonesian law on natural resources gives responsibility of ownership and management to the state making it quite difficult for private investment inflow in the energy sector. President Soeharto established BAROKEN (Badan Koordinasi Energi Nasional) in 1980 to provide a guideline to future energy policies. ${ }^{18}$ BAROKEN then published 5 main policies in 1997 known as KUBE (Kebijakan Umum Bidang Energi) which includes (1) Energy Diversification, (2) Intensification of Energy Resources Exploration Policy, (3) Energy Conservation Policy, (4) Energy Pricing Policy, and (5)

\footnotetext{
${ }^{15}$ Ibid

${ }^{16}$ Ibid

${ }^{17} \mathrm{Ibid}$

${ }^{18}$ Trichandi, Rahmantara. “A Brief Review on Indonesia's National Energy Policy”. The Opinion. (2018): https://publication-pyc.org/wp-content/uploads/2018/12/A-Brief-Review-on-Indonesias-National-Energy-Policy.pdf.
} 
Environmental Policy. ${ }^{19}$ Building of main objectives from KUBE, a line of bureaucracy for decisionmaking is then formed. Through several revisions, DEN was established to (1) propose energy policies to then be agreed upon by the House of Representatives (DPR), (2) implement the policy through RUEN (Rencana Umum Energi Nasional), (3) provide energy policies in times of an energy emergency, and (4) ensure proper implementation of energy policies in all related sectors. It should also be noted that DEN is headed by the President with members from the Minister of Finance, Minister of National Development Planning, Minister of Transportation, Minister of Industry, Minister of Agriculture, Minister of Research and Higher Education, and Minister of Environment. This heavy set of members are included to ensure that the proposal of energy policies coming from DEN will benefit related sectors.

In 2014, DEN released KEN (Kebijakan Energi Nasional) as organized by Government Regulation PP No. 79/2014 as an energy management policy that focuses on establishing sustainability, and environmentally-friendly policies in hoped of creating energy independence and national energy security. An important development KEN brought for Indonesia's energy policies is that it is no longer centralized to the President. KEN can be reviewed every 5 years unless there is an emergency. Afterwards, RUEN and RUED (Rencana Umum Energi Daerah) is formally made with an ambitious goal where $23 \%$ of Indonesia's energy mix being renewable by 2025 . RUEN also highlights that Indonesia will still be mainly sourced by fossil fuel such as coal (30\%), natural gas (22\%) and crude oil (25\%). This goal compliments Indonesia's commitment in international forums in pledging dedication for renewable energy. Notably, Sujatmiko acting as the Head of Public Communications for the Ministry of Energy and Mineral Resources (ESDM) mentions that the 23\% of renewable energy will include nuclear energy. ${ }^{20}$ There are some concern on this as the nuclear itself is renewable but a nuclear power plant is not. This should be noted as debates on nuclear energy stipulates that it is not to be considered as renewable. However, this paper will recognize nuclear energy in the category of renewable energy to align with Indonesia's current policy.

\section{b. Before COVID-19 Outbreak: Security as Availability and Sustainability}

Indonesia is the most populous country in the Southeast Asia region. Hence, it is no surprise that the energy usage remains high. However, as energy usage in rural communities are somewhat limited by ability to purchase, Indonesia can still keep up with the energy demands. KEN established that the state's energy policy objectives are to (1) secure energy supply at affordable prices, (2) enhancing the quality of living, (3) stimulate economic growth, and (4) reserving adequate amount of oil and gas. ${ }^{21}$ To achieve the aforementioned goals, the state aims to intensify the exploration of energy sources, diversify the commodity of energy sources, and conserve energy production and utilization. $^{22}$

Understanding that the oil and gas reserves are not permanent, the state has started to innovate in energy development. The fact that oil and gas serve as a main export commodity for the country also makes it urgent to explore other sources. One of the most prominent projects for an alternative source centers on nuclear energy. Interestingly, the regulations on nuclear development in Indonesia

\footnotetext{
${ }^{19}$ Rahmantara Trichandi, A Brief Review on Indonesia's National Energy Policy.

${ }^{20}$ Sihite, Gabriela Jessica Restiana. "Nuklir Masuk dalam Rencana Umum Energi Nasional”. Media Indonesia. (2016):

https://mediaindonesia.com/read/detail/56918-nuklir-masuk-dalam-rencana-umum-energi-nasional

${ }^{21}$ Soedyartomo Soentono, Nuclear Power Development in Indonesia.

22 Ibid.
} 
predates the formation of official energy policies. Nonetheless, nuclear energy is seen as a cleaner alternative to fossil fuels. Seeing that RUEN forecasted a $77 \%$ dependence on fossil fuel by 2025 , a development in nuclear energy is aimed to minimize our reliance on all fossil fuels. Aligning with the 1964 Decree number 31, concerning the main regulations for atomic energy, nuclear energy can only be used for peaceful purposes. ${ }^{23}$ This led mandated the Badan Tenaga Atom Nasional to supervise and implement the use of nuclear energy in the state. Numerous studies on the role of nuclear energy in Indonesia has been done. Some to show the community response which shows momentary reluctance due to the Fukushima incident but is now relatively accepted. ${ }^{24}$

Others show that Indonesia has researched on nuclear energy since 1970s. ${ }^{25}$ Furthermore, the state planned for the emergence of nuclear energy since 1997 and to be implemented by $2007 .{ }^{26}$ However, the economic crisis of 1997-98 halted the investments going into developing this project. Seeing that the electrical current outside of the Java-Bali area is more limited, these nuclear plants aimed to even out the energy supply to the whole state. A nuclear power plant that is ship based was also considered following the Madura black-out of 1998. The idea for nuclear energy was then reaffirmed again during the reform by President Wahid. Afterwards, President Megawati signed a bilateral cooperation with Russia to develop, construct, and operate nuclear power plants. It was not until 2004 when Yusgiantoro, the Energy Minister at the time, adopted the Kebijakan Energi Nasional (KEN) when nuclear energy is formally and legally recognized. ${ }^{27}$ Fear of the Fukushima and Chernobyl incident puts a heavy emphasis on a safe nuclear power plant. This is also the reason why, to this day, state officials reiterate that nuclear remain the last option for Indonesia.

Above shows that the focus of Indonesia on energy security revolves around the availability itself. Although one of the energy objectives was to ensure availability of energy with an affordable price, the development of nuclear energy became the main focus. Even as a last priority, tremendous efforts were still made to have nuclear energy as a safety net. It can be said that, relying on the free market, availability is anticipated to pull the process down making it more affordable. The early steps of researching, pulling investments, publicizing to implementing shows the state's dedication on diversifying their energy source. Hence, it is safe to say that Indonesia highlights security as availability when talking about energy security.

The idea is that the introduction of nuclear energy can substitute the use of oil in major energy sectors such as industry, electrification, household, and transportation. The goal is that by $2025,2 \%$ of the overall primary energy of the state will come from nuclear power plants. ${ }^{28}$ Furthermore, studies show that this is also companied by the goal of sustainability. The efforts of planning a sustainable energy system through cogeneration, revision of fuel cycle and utilization of nuclear technology for renewable resources is done in regards of environment. While some argue that nuclear generator is not significant enough to do so, it should be seen as a start. In this regard. It can be seen that the state also focusses on security as sustainability when talking about energy security.

\footnotetext{
${ }^{23}$ Ibid

${ }^{24}$ Fauzan, Achmad Uzair and Jim Schiller. "After Fukushima: The Rise of Resistance to Nuclear Energy in Indonesia”. $A D B$ Project. (2011): http://www.lebret-irfed.org/IMG/pdf/resistance-in-indonesia-after-fukushima.pdf.

${ }^{25}$ Soedyartomo Soentono, Nuclear Power Development in Indonesia.

${ }^{26}$ Su'ud. "The Role of Nuclear Energy in Indonesia in the $21^{\text {st }}$ Century". Bandung Institute of Technology. (2003): https://www.ipen.br/biblioteca/cd/genes4/2003/papers/1227-final.pdf.

${ }^{27}$ Achmad Uzair Fauzan and Jim Schiller, After Fukushima: The Rise of Resistance to Nuclear Energy in Indonesia.

${ }^{28}$ Soentono, Soedyartomo and Ferhat Aziz. "Expected Role of Nuclear Science and Tehnology to Support the Sustainable Supply of Energy in Indonesia”. Elsevier. (2007): https://doi.org/10.1016/j.pnucene.2007.10.021..
} 
Interestingly, the approach of non-traditional on the local level is understood but not focused on. This is as if the task of a government is to make sure of the availability of energy but the affordability itself is not seen as a mandatory task. Hence, the elaboration above shows how Indonesia's energy security before COVID-19 focus more on security as availability and sustainability.

\section{c. After COVID-19 Outbreak: Security as Affordability}

Before arguing Indonesia's focus shift, it is imperative to look at the development of previously started projects related to energy. Studies on the importance of nuclear power plants for energy security throughout the pandemic have also continued. This shows that it is not as if the government have abandoned the nuclear developments completely to focus on subsidies and bill extension. More importantly, it is to show that the focus itself on energy security is deepen and widen towards security as affordability.

Originally, the Indonesian government have already made diesel generators to be a standard of rural electrification solution. ${ }^{29}$ This can be seen as securing availability and affordability. However, due to the pandemic, it can be said that the government is now focusing more on security as affordability. In a sense, the decreased demand for energy outside the household market created a short relieve in the issue of availability. The pandemic has created a difficult situation where people have to work from home with limited social contact. Although some companies are able to accommodate to these circumstances, a lot of Indonesians are let go from their employment. Whether it is formal or informal employment, people are losing their jobs left and right. This means that, in addition to households who already have a problem keeping the lights on, more families are now facing the same problem.

Data shows that the demand of household electricity actually increased significantly since the outbreak due to the prolonged activities at home as well as elevated use of electric gadget. Outside of day to day activities like cooking and turning on the lights, internet access has also become a pivotal commodity to keep up with the New Normal. In regards to that, more and more households are unable to afford basic electricity let alone maintaining an internet connection. This is supported by a report from Energy and Mineral Resources Ministry stating that 1.2 million families are unable to access internet connectivity. From that number, 400 thousand of these families are located in Maluku, Papua, and Nusa Tenggara. Left alone, this can intensify disparities in the education and economic sector. This raises the concern of affordability to the top of the list.

The government have already shifted their focus on this affordability issue by highlighting it as a crucial form of energy security. Seen from the program made by the state-owned energy company, Perusahaan Listrik Negara (PLN), efforts like subsidies or extension of bill payment are done. These are targeted for households unable to pay their electric bill. The electricity subsidy scheme is aimed for people with pre and postpaid PLN customers from the 450 VA and $900 \mathrm{VA}$ categories. ${ }^{30}$ Specifically, Rp 3.5 trillion are allocated for the prepaid customers while relief schemes are given to the postpaid customers. Extension of the bill refers to allowing people to pay only $40 \%$ of

\footnotetext{
${ }^{29}$ Abidah B. Setyowati, Mitigating Energy Poverty: Mobilizing Climate Finance to Manage the Energy Trilemma in Indonesia.

${ }^{30}$ Harsono, Norman. "Over a Million Low-Income Households Left Out of Electricity Relief Scheme". The Jakarta Post. (2020): https://www.thejakartapost.com/news/2020/04/16/over-a-million-low-income-households-left-out-of-electricityrelief-scheme.html.
} 
the June bill and the rest being evenly distributed to the upcoming months. ${ }^{31}$ This measure was taken because PLN saw a $344 \%$ rise in electric bill throughout June. To accommodate concerns, PLN also intensified their customer service through call services and home visits.

Aside from that, the Ministry of energy and mineral resources put out an official letter to PLN in regards to decreasing electricity tariffs. Known as Tariffs Adjustment, the initiative will be targeted to customers with no subsidy. ${ }^{32}$ As for Liquified Petroleum Gas (LPG), the request for its price to be decreased or receive additional subsidy has been made since 2016. However, demands for more subsidy for 3 kilograms of LPG is still debated for 2021. ${ }^{33}$ Although the gas market has made prices fall naturally, concerns about affordability becomes a concern in the meeting of Ministry of energy and mineral resources. This again shows synchronicity between Indonesia's energy policies with the current international focus. It shows that both domestic and international actors highlights energy security as affordability more than other concepts.

Although these steps are seen to be helpful, some argue that it is only a short-term solution. It does not actually empower the communities to be independent enough to have energy security. However, perhaps the uncertainty of the COVID-19 situation makes a short-term solution more suitable. On the bright side, this pandemic actually brings more attention to the energy insecurity of Indonesian rural areas. Hence, it is imperative to keep the government accountable on fully establishing security as affordability.

\section{d. External factors}

Following the notion that state's activities will never be fully devoid of international pressure, we can see the synchronicity between global energy security focus and Indonesia's before the pandemic. As previously stated, a commitment in achieving SDG 7 as well as alignment to the Paris Agreement guides member states to start developing alternative energy sources. As a supporter of SDGs and a signatory with ratification of the Paris Agreement, Indonesia do not fall short of efforts to develop alternative energies. Perhaps this is why Indonesia focused on security as sustainability in the very first place - as a form of international compliance. In other words, Indonesia's commitment to the Paris Agreement also puts external pressure to the state for reducing carbon footprints.

Taking IOs into account, the International Energy Forum (IEF) became a medium to connect consuming, producing, and transit countries of the International Energy Agency (IEA). The main goal is to secure the supply chain of the oil industry from any enforceable events. Any anticipated 'disruption' to the global chain are most likely to be similar with the oil embargo as in how states can coordinate better with one another to not disrupt the chain. This then becomes a small consideration leading to Indonesia's concern on security as availability.

As a response to the pandemic, the G-20 have met with IEF and other member states to talk about the concerning disruption towards the global oil demand due to the pandemic. ${ }^{34}$ OPEC meetings also shows reluctance of big oil exporters like Russia and Saudi Arabia to curtail their energy

\footnotetext{
31 Iskana, Febrina Ratna. "Tagihan Listrik Juli 2020 Melonjak Lagi, Begini Perhitungan PLN". Katadata. (2020): https://katadata.co.id/berita/2020/07/03/tagihan-listrik-juli-2020-melonjak-lagi-begini-perhitungan-pln.

32 Asmarini, Wilda. "Pemerintah Turunkan Tarif Listrik, PLN: Siap Laksanakan!”. CNBC. (2020): https://www.cnbcindonesia.com/news/20200901173758-4-183673/pemerintah-turunkan-tarif-listrik-pln-siap-laksanakan.

${ }^{33}$ Ramadhani, Pipit Ika. "DPR Minta Pemerintah Kaji Ulang Penurunan Subsidi LPG 3 Kg di 2021”. Liputan6. (2020): https://www.liputan6.com/bisnis/read/4345887/dpr-minta-pemerintah-kaji-ulang-penurunan-subsidi-lpg-3-kg-di-2021 .

34 Jacob, Shine. "G-20 Energy Ministers Bat for Cheaper Energy Supplies to Support Healthcare". Business Standard. (2020): https://www.business-standard.com/article/economy-policy/g-20-energy-ministers-bat-for-cheaper-energy-suppliesto-support-healthcare-120041001378_1.html.
} 
production and as well as managing export prices. ${ }^{35}$ This shows how it is not only that the global value chain is disrupted, but the diplomatic relations between big players are also challenged. G-20 talks about energy bill subsidy, brought up by the representative of India, became the main focus. Expressing the concern for decreased productivity, India highlights the importance of member states to support members of society in affording electricity. A similarity in India's action and Indonesia's shows how the current focus of security as availability is not only seen in Indonesia.

Understanding the aforementioned external factors should only be seen as a context comprehend Indonesia's position and decision-making. Although we cannot doubt that external pressure may influence a country's policy, this case shows how Indonesia's domestic factor plays a bigger role. This is because, actions following the footsteps of Russia and Saudi Arabia who chose to focus on economic profits in a time of crisis is a plausible scenario. In spite of that, Indonesia sees the demands of its people and chooses to shift its focus on security as affordability to rebuild the economy of middle to lower class society.

\section{Conclusion}

All in all, it is certain that Indonesia' focus on energy security has shifted as it is also impacted by both international commitments and domestic conditions. Developments on alternative energy like nuclear as well as renewable energy like solar and wind power have shown commitments on a more sustainable energy. Both international and domestic efforts have been made to further improve the production of energy. However, COVID-19 acts as a force majeure in accomplishing SDG 7.

This led to a shift in the focus of the government regarding energy security. The data elaborated above shows the different reaction of the Indonesian government towards energy insecurity before and after the COVID-19 outbreak. Before the outbreak, this insecurity is planned to be solved by developing nuclear power plants to secure energy supply in hopes of making it more available and sustainable. After the outbreak, the government actually take the extra step of subsidizing and extending the electric bill to minimize the impact of economic downturn over energy insecurity.

After realizing this, the arduous task of keeping the government accountable to ensure equal distribution of energy then becomes ours. It is concerning that neither RUEN or RUED provided interim policies to mitigate COVID-19 impacts. Hence, even though a focus on affordability is apparent right now, there is no guarantee of its significance after the pandemic. Most articles mentioned how the pandemic is affecting the implementation and planning of RUED. Unfortunately, no there are no clear indications that long-term adaptation plans are to be established. A long-term effort and solution to empower all of Indonesia to be independent and secure in regards to electricity is needed. Perhaps the immediate solutions offered by the government can be considered to be the first phase of promoting economic development through affordability of electricity. Then, security as affordability can first be established before shifting back the focus.

\footnotetext{
${ }^{35}$ Ladislaw, Sarah. “The End of OPEC or a New Beginning?". Center for Strategic and International Studies. (2020): https://www.csis.org/analysis/end-opec-or-new-beginning.
} 
134 Jovita Komala | Indonesia's Shifting Focus of Energy Security Amidst COVID-19

\section{Reference}

\section{Books}

Buzan, Barry. Ole Wæver and Jaap de Wilde. (1998). Security: A New Framework for Analysis. United States: Lynne Rienner Publishers, Inc.

Caballero-Anthony, Mely. (2016). An Introduction to Non-traditional Security Studies: A Transnational Approach. Edited by Mely Caballero-Anthony. United States: SAGE Publications Ltd.

\section{Journals}

Fauzan, Achmad Uzair and Jim Schiller. "After Fukushima: The Rise of Resistance to Nuclear Energy in Indonesia”. ADB-Project. (2011): http://www.lebret-irfed.org/IMG/pdf/resistance-inindonesia-after-fukushima.pdf. [Accessed July, 12 2020]

Setyowati, Abidah B. "Mitigating Energy Poverty: Mobilizing Climate Finance to Manage the Energy Trilemma in Indonesia". School of Regulations and Global Governance. (2020): https://doi.org/10.3390/su12041603. [Accessed on July, 10 2020]

Soentono, Soedyartomo and Ferhat Aziz. "Expected Role of Nuclear Science and Tehnology to Support the Sustainable Supply of Energy in Indonesia”. Elsevier. (2007): https://doi.org/10.1016/j.pnucene.2007.10.021. [Accessed 13 July, 2020]

Soentono, Soedyartomo. "Nuclear Power Development in Indonesia". National Atomic Energy Agency. (1996): http://waste.nuc.berkeley.edu/asia/1997/97ILP Soentono.pdf. [Accessed July, 12 2020]

Su'ud. "The Role of Nuclear Energy in Indonesia in the $21^{\text {st }}$ Century". Bandung Institute of Technology. (2003): https://www.ipen.br/biblioteca/cd/genes4/2003/papers/1227-final.pdf. [Accessed 16 July, 2020]

Trichandi, Rahmantara. "A Brief Review on Indonesia's National Energy Policy". The Opinion. (2018): https://publication-pyc.org/wp-content/uploads/2018/12/A-Brief-Review-on-IndonesiasNational-Energy-Policy.pdf. [Accessed 18 September, 2020]

Williams, Michael C. "Words, Images, Enemies: Securitization and International Politics". International Studies Quarterly. (2003): DOI: 10.1046/j.0020-8833.2003.00277.x. [Accessed 31 July, 2020] 
135 Jovita Komala | Indonesia's Shifting Focus of Energy Security Amidst COVID-19

\section{News Articles}

Asmarini, Wilda. "Pemerintah Turunkan Tarif Listrik, PLN: Siap Laksanakan!". CNBC. (2020): https://www.cnbcindonesia.com/news/20200901173758-4-183673/pemerintah-turunkan-tariflistrik-pln-siap-laksanakan. [Accessed 29 November 2020]

"World Energy Demand to Drop 6\% in 2020: IEA". Greentechlead. (2020): https://greentechlead.com/renewable-energy/world-energy-demand-to-drop-6-in-2020-iea$\underline{35993}$. [Accessed on July, 11 2020]

Harsono, Norman. "Over a Million Low-Income Households Left Out of Electricity Relief Scheme". The Jakarta Post. (2020): https://www.thejakartapost.com/news/2020/04/16/over-a-millionlow-income-households-left-out-of-electricity-relief-scheme.html. [Accessed July, 11 2020]

Iskana, Febrina Ratna. "Tagihan Listrik Juli 2020 Melonjak Lagi, Begini Perhitungan PLN". Katadata. (2020): https://katadata.co.id/berita/2020/07/03/tagihan-listrik-juli-2020-melonjaklagi-begini-perhitungan-pln. [Accessed July 12, 2020]

Jacob, Shine. "G-20 Energy Ministers Bat for Cheaper Energy Supplies to Support Healthcare". Business Standard. (2020): https://www.business-standard.com/article/economy-policy/g-20energy-ministers-bat-for-cheaper-energy-supplies-to-support-healthcare-120041001378_1.html. [Accessed July 10, 2020]

Ladislaw, Sarah. "The End of OPEC or a New Beginning?". Center for Strategic and International Studies. (2020): https://www.csis.org/analysis/end-opec-or-new-beginning. [Accessed July, 10 2020]

Ramadhani, Pipit Ika. "DPR Minta Pemerintah Kaji Ulang Penurunan Subsidi LPG 3 Kg di 2021”. Liputan6. (2020): https://www.liputan6.com/bisnis/read/4345887/dpr-minta-pemerintah-kajiulang-penurunan-subsidi-lpg-3-kg-di-2021 . [Accessed 29 November 2020]

Sihite, Gabriela Jessica Restiana. "Nuklir Masuk dalam Rencana Umum Energi Nasional”. Media Indonesia. (2016): https://mediaindonesia.com/read/detail/56918-nuklir-masuk-dalam-rencanaumum-energi-nasional. [Accessed 18 September, 2020] 